\title{
Turning round the telescope. Centre-parties and immigration and integration policy in Europe
}

Tim Bale

\section{Politics and Contemporary European Studies, University of Sussex}

A recent 'state of the art' review of the political science literature on migration notes that myriad studies 'have provided evidence that a range of actors influence policy outcomes. They include organised interest groups, courts, ethnic groups, trade unions, law and order bureaucracies, police and security agencies, local actors and street-level bureaucrats and private actors' (Lahav and Guiraudon, 2006: 207). Missing from the list (although, to be fair, they later make a brief appearance in a table as 'conduits of public opinion') are organisations that one might have expected to have had some say in the matter. Their absence, however, is not unusual even if it is curious: as a contribution to one recent edited collection puts it, "political parties have received relatively short shrift among students of the politics of migration'; they 'enter the story as minor characters with undefined roles' (Triadafilopoulos and Zaslove, 2006: 171, 176)

This is almost certainly because, with a handful of exceptions (Hammar, 1985, Perlmutter, 1996, Schain, 1999 and 2006, Geddes, 2003, Givens and Luedtke, 2005, Williams, 2006 and, interestingly, Lahav, 2004), the political science communities 
working on asylum and immigration, on the one hand, and parties, on the other, have traditionally sat at separate tables. Leading migration scholars have rightly nodded to the need to understand how the arrival of newcomers and their families impacts on attitudes and electoral politics (see, for example, Hollifield, 2000: 170-1). But very few treat the parties that fight those elections as a vital source of state and EU policy policy which for some time now has been moving towards an emphasis on restriction and cultural integration that borders on the coercive (see Joppke, 2007). Meanwhile, scholars of contemporary party politics often talk about the backlash against migration and multiculturalism. But they do so largely in two limited contexts. The first is research into the phenomenon of far-right parties (see, for example, Carter, 2005, Norris, 2005, Rydgren, 2005, and Mudde, 2007). The second - in a manner reminiscent of arguments concerning public opinion and party positions on European integration - is the question of whether the debate on migration and multiculturalism cross-cuts traditional constructions of the left-right dimension or, as would seem to be the case, be collapsed into it (see Gabel and Anderson, 2002 and McElroy and Benoit, 2007).

Policy people, in other words, don't really do parties, while party people do policy only insofar as it affects party competition and positioning. This talking past each other is a great pity for those who, in general, see merit in joined-up political science rather than the logic of specialisation that encourages us all to know more and more about less and less. Few of us, after all, have given up completely on the notion that there is a real world out there that we have some kind of mission to explain. Often we do this by using heuristics that make our task more manageable and our findings 
easier to communicate. But, if so, we need to ensure that we extract full value from the explanatory frameworks we employ. Hence, if as experts on political parties we believe their motives and dilemmas can be usefully modelled by declaring they must trade off between 'policy, office, and votes' (Müller and Strøm, 1999) then we need to take the first every bit as seriously as the other two. By the same token, if we believe, as many who study migration policy believe, that, we need to focus on 'the liberal state' (Hollifield, 2000: 146-150) or on organised interests calculating costs and benefits (Freeman, 1995) or on inertia-prone institutions (Hansen, 2002), then it seems only sensible to pay attention to the 'critical nodes' (Triadafilopoulos and Zaslove, 2006: 189) that connect, influence, and are influenced by, all these things, namely political parties.

\section{Why (mainstream centre-right) parties matter}

Political parties matter to European public policy on migration because 'the nationstate is...where the majority of the migration action lies' (Lahav, 2004: 10) but they will continue to do so even if the action moves elsewhere. Recent work by migration scholars emphasises the capacity and desire of EU member states not to cede competence in such a sensitive area unless it suits them (see, for example, Geddes, 2003 and Messina, 2007). But even those scholars more inclined to look for evidence of Europeanisation routinely emphasise that it involves the 'uploading' of policy to the EU by member states as well as its 'downloading' to the member states by the EU (Börzel, 2002). Given that the direction and detail of state policy demonstrably depends on who governs (Schmidt, 1996 and Imbeau et al., 2001), this means that 
parties are highly likely to count for something on immigration and integration irrespective of whether states refuse or decide to cede (or at least share) sovereignty in those areas. And should things move even further beyond the state, parties will still count for something. Immigration and integration may eventually become subject not just to instrumental intergovernmental co-operation but to full-blown community competence. Even, then, however, they will be amenable to influence by political parties that are increasingly coherent and cohesive at the transnational level (see Hix and Noury, 2007). In other words, it is not just in (migration) policy-making that one finds Europeanisation (see, for example, Lavenex, 2007): parties, too, are eventually affected, albeit in an equally uneven, contested and normatively problematic manner (see Mair, 2006). As long, then, as representative politics remains a feature of both the nation-state and that which transcends (or at least enmeshes) it, there is no escape from parties.

The logical corollary of acknowledging the potential influence of parties on public policy in this and other areas would be to look first at those parties which have spent most time in government, either singly or in coalition. One study (Givens and Luedtke, 2005) made a promising step in this direction, even if its discovery that there is more difference between left and right governments on integration policy than on immigration has to be tested on a wider range of countries (and over a longer timespan) before it can be regarded as anything more than indicative. For some reason, however, most of those who have dealt with the issue of party impact have chosen to look, as it were, down the wrong (or at least the other) end of the telescope at the putative influence of 'fringe' or 'extremist' parties rather than that more 
obviously exercised by the 'mainstream' parties which by and large have kept them, and continue to keep them, out of government. Clearly, the issue of whether these smaller parties have - often indirectly - influenced public policy on immigration and integration is both interesting and important, as a number of stimulating studies, both recent (Schain, 2006, Williams, 2006, and Triadafilopoulos and Zaslove, 2006) and slightly older (Minkenberg, 2002), have demonstrated. It is about time, however, that we turned the telescope round and trained it, too, on the parties with a more direct impact on public policy at and beyond the level of the state. In this respect, parties of the centre-right which, despite their crucial importance to the past, current, and future governance of the continent, have enjoyed nowhere near the scholarly attention of their more radical counterparts, are an obvious point of departure. ${ }^{1}$ And what better journal to host such an exploration than one which concerns itself with public policy made at both the 'domestic' and the 'European' level, as well as in the interstices between the two.

Many mainstream parties that have a chance of forming - or helping to form governments in contemporary Europe are under pressure to take a harder-line, more restrictionist and 'assimilationist' stance on issues of immigration and integration. The sources of such pressure obviously include real-world problems such as increased labour migration and asylum seeking, stretched border security, welfare and criminal justice systems, the threat of terrorism, and the evident unease about cultural differences in some segments of the self-styled 'native' population. Mainstream parties are also under pressure from radical, populist alternatives, from a media that 'compares immigrants in generous moments with thieves, in less generous moments 
with sewage' (Hansen, 2003: 32), and from their own members, supporters and electorates, with considerable feedback between each of these forces. Clearly the perceived problems and the apparently pressing need for solutions are in part cued and constructed by political (and especially government) actors (see, for example, Statham, 2003: 170-1, 175). Demand is not independent of supply, as any successful entrepreneur - electoral as well as economic - knows. Nor does one need to buy wholesale into constructivism or postmodernism to realise that, when it comes to how voters think about immigration and asylum, 'perception is reality' - particularly when it comes to the numbers involved (see Sides and Citrin, 2007). But all this is true only up to a point. If we are to gain an understanding of the policy pursued by mainstream political parties, we have to acknowledge what for some of us may be uncomfortable realities.

In other words, even if we discount for the inflated figures bandied about by opponents of immigration, the decades since the end of the cold war have seen large numbers of people hoping to work, or take refuge from persecution, in western Europe. Since 2004 these numbers have been swelled by the accession to the EU of twelve mainly Central and Eastern European states and may in a decade or so be boosted even further by the entry of Turkey. While the numbers may be small relative to the existing population, they are - or can be made to look - huge in absolute terms, especially if the faces, languages and cultures of the migrant population and their descendents seem very different. By the same token, only a minority of entrants rely on, or even abuse, Europe's welfare systems. But some of course do, either because they are encouraged to by a benefits regime that requires little in return for the 
assistance it provides or because they are trapped into doing so by overt and covert discrimination that prevents them from escaping dependence. Similarly, it may well be that ethnic minorities who are either the descendants of migrants or migrants themselves, are overrepresented in the criminal justice system not just because they are poor but also because law enforcement agencies pay them an inordinate amount of attention and hand them down tougher sentences. But overrepresented they are. Equally, they are not the only people to be involved in terrorism in Europe, and the threat may indeed be exaggerated out of all proportion. Yet, the most recent and most high-profile attacks have indeed been instigated by extremists from (or with roots) outside Europe - and their atrocities have been all too real. It is the real world, then, and not just the fevered imaginings of demagogues and ill-informed, culturally threatened voters that poses real policy questions for politicians.

Parties operating on the centre right - our focus here - are perhaps particularly preoccupied with such questions. In other words, we should expect them to care irrespective of (or at least in addition to) electoral considerations. Part of their raison d'etre, after all, is to defend the socio-economic and cultural status quo to which the entry of large (or at least highly visible) numbers of migrants would appear to present something of a challenge. Just as traditionally, they are in favour of keeping tax low, ensuring law and order is maintained and national security is protected - all aims that are apparently threatened by ethnic minorities that have for some time been overrepresented in the welfare rolls and crime statistics (Joppke, 2007: 6), and now, in the era of 9/11, and the bomb attacks on Madrid and London, are thought to present an even more dramatic threat (see Karyotis, 2007, and also Collyer, 2006 and 
Hampshire, forthcoming). Parties of the centre-right also have an ambivalent relationship with the parties that play up such threats: on the one hand, the far right may eat into their vote share (the preoccupation of much of the literature); on the other, it may help them into office by joining or supporting governments they lead. Accordingly, calling for the tightening of borders and sounding off against the evils of multiculturalism might serve to counter the electoral threat from radical right wing populists or, by boosting the salience of the issues that such forces thrive on, it might increase their vote share and help the more respectable right to win back or maintain office (Bale, 2003; see also Meguid, 2005). Whatever, a hard-line stance must be quite a temptation, especially if it is consonant with, or no more than a logical extension of, one's own ideological position.

Some migration scholars, however, would deny that there is much of a correlation between being on the right of centre and greater concern about inflows and greater insistence on integration; immigration, apparently, 'is located at the crossroads between two very different semantics: those based on economic or functional issues... and those based on culture, identity and tradition', thus rendering 'the distinction between conservative and progressive' problematic if not meaningless (Sciortino, 2000: 224-5). Such assertions seem to be contradicted by empirical evidence: Lahav (2004: 126-132) shows that there is a clear ideological and party distinction between the conventional left and right on these issues and that one doesn't have to look too far along the right hand side of the divide before attitudes become restrictive and suspicious (see also Lahav, 1997). Put bluntly, centre right voters and the parties they vote are indeed more preoccupied about immigration and integration, are more likely 
to kick up over such issues, and have been for quite some time, even in the absence of a significant far right threat (Perlmutter, 1996). Expressing the desire to protect 'us' from 'them', whoever or whatever 'them' (or 'the other') may happen to be at the time, is in what Panebianco (1988) calls the 'genetic code' of many mainstream centre-right parties - and arguably, given the 'racialised' nature of European society and history, their centre-left counterparts cannot claim to be totally immune either (see Garner, 2005: 125).

This is a very important point. Framing the centre right's (and indeed the centreleft's) stand on immigration control and immigrant policy as purely, or at least primarily, a strategic response to the populist radical right implies that Europe's mainstream parties are somehow incapable of coming to their own conclusions on the seriousness of the issues and the policy direction they should take on them. This is not only potentially patronising, it is misleading - as even scholars determined to find far right influence are wise enough to acknowledge in the small print (see Williams, 2006: 69-70) . Moreover, given the fact that supposedly more 'progressive' parties are under as much, if not more, pressure from populist entrepreneurs aiming to steal their voters, the 'far-right pressure' frame doesn't explain why it has so often been the centre-right that has made the running on immigration control and more aggressive integration rather than the centre-left - even if the centre left has eventually followed suit (see Bale et al., 2007). If political competition is indeed about 'issue ownership' and campaigning about 'selective emphasis' - about parties talking past each other because they are preoccupied with moving the agenda onto issues on which they are 'strong' (see Budge and Farlie, 1983) - then the centre-right has had a claim to own the issues we deal with here for some time. 


\section{Little prodding needed: the record of the centre-right on immigration and integration}

To read or hear some accounts, both in the media and in more academic work, however, one would think that it is only since the 'rise of the far right' that countries and by implication centre-right parties - have been worrying about and taking action on immigration and integration. But the now familiar notion that there was a more or less bipartisan (and ultimately counterproductive) 'conspiracy of silence' on the part of the mainstream that created 'a political space' for the anti-immigrant extreme which now needs closing down (see, for example, Messina, 2007: 86-7) is problematic. It did not require, for instance, a far-right threat to bring about the almost pan-European 'immigration stop' in the early 1970s. It is abundantly clear, for example, from the policy debate and measures in post-war France that 'mainstream' politicians, especially (though not exclusively) on the centre-right have been active in this area since for well over thirty years. True their efforts and rhetoric intensified after, first, 1986 and then 1993, when the Front National was clearly seen as an electoral threat. But we have to remember that the latter year also marked a dramatic increase in anxiety about the security threats allegedly posed to France by (Algerian) migrants (see Collyer, 2006): no-one who saw or heard Charles Pasqua - France's Minister of the Interior who spearheaded the government's hard line on immigration and integration - in action would have argued that he was reluctantly driven into such a stance simply in order to head off Le Pen. We also need to recall that it was 1974, under Giscard (and Chirac) and long before Le Pen was taken so seriously, that 
'marked a seachange' which saw immigrants regarded 'more as a liability than as an asset' (Hollifield, 1994: 155).

But France was by no means alone in seeing the centre-right taking immigration and (albeit to a lesser extent) integration seriously before, and not wholly because of, the far right (or, for that matter, Osama bin Laden). Etzinger's fascinating account of the (note, pre-Pim Fortuyn) retreat from multiculturalism - in as much as it ever really existed as official policy (see Joppke and Morawska, 2003: 1) - may not mention parties as much as some of us think it might (Entzinger, 2003). But it does serve as a useful reminder that it was the leader of the market- or conservative-liberal VVD, Frits Bolkestein who, in September 1991, triggered a national debate by declaring the incompatibility of Islam and 'Western values' and insisting immigrants should adapt to the host culture rather than the other way around. Unless we are willing to label a future European Commissioner (1999-2004) as a populist radical right-wing entrepreneur à la Blocher, Haider et al., then we have to acknowledge that, if it was this intervention that in part provoked the Dutch government to re-direct its efforts away from minority promotion and toward integration, it came from a mainstream not the extreme.

Germany is another case in point. The CDU-CSU-FDP coalition won the first election of the 1980s "in part on the grounds that it would "do something" about immigration' (Martin, 1994: 203); at that point, however, there seems to have been relatively little anxiety about a resurgent far-right. Some will of course argue that German politicians are, for obvious historical (and indeed diplomatic) reasons hyper- 
vigilant about such a resurgence, and that even its possible (as opposed to actual occurrence) can therefore be wheeled in as an explanation of their growing determination to crack down since, say, the late 1970s. But this doesn't explain, firstly, why they didn't act in the late 1960s when fears of the far-right were more apparent. Nor, secondly, does it explain why it was the centre-right rather than the centre-left (presumably every bit as sensitive to the far-right threat) that over the last thirty years has taken a harder line.

The argument that Germany's centre-right acts because it fears the far-right dovetails with a wider presumption that mainstream politicians somehow require public opinion to be channelled or mediated by a populist political entrepreneur before they act even when that opinion is clearly running in one direction and can in part be explained by a massive absolute increase in numbers coming (or trying to come) into the country, as well as the fact that some of minorities already there are clearly not well-integrated. Just as importantly, it ignores the indisputable point that in Germany the far-right never seems to make the breakthrough into national politics that in other countries - not least France - is apparently responsible for policy shifting towards restriction and intolerance. Perhaps if we could see beyond Germany's Nazi past, we might be able to locate its mainstream politicians' attitudes and actions on immigration and integration in the party system the country currently has rather than in the one some fear it might one day have again. Doing this might lead us to look at, for example, at Germany's constituency-based electoral system. If such a system is indeed part of the reason why British politicians respond so quickly to public 
anxieties about immigrants (see Money, 1997), then might it also explain why their German counterparts pick up on them too?

It is perhaps no accident that it is in the UK, with its two (or two-and-a-half) party system and absence of a fascist past, that policy and parties have been most closely tied together by migration specialists (see, for example, Spencer 1997). But the UK should not be alone - something that becomes obvious the more one thinks about it. Given the examples of radical right-wing populist involvement in government in Italy and Austria (and we would also include Denmark where minority governments of the centre right have in recent years relied on parliamentary support by the populist radical right), Garner (2005: 133) might be overstating the case when he argues that the racialised nature of immigration control and immigrant policies in Europe is quite simply 'a result of mainstream politics.' But he has a point: even outside the UK, what he calls 'the logic of defence' (ibid.) was around long before the far-right became a force to be reckoned with once again.

The predictable retort to this counterblast is that any failure of the extreme right in UK (or indeed Germany) is, at least in part, testimony to the fact that a hard-line stance by the mainstream right works to close down the issue space: cue endless misquotations of soon-to-be prime minister Margaret Thatcher's famous remark to a television interviewer in the late 1970s concerning people's fears of being 'swamped' - a remark which, to read some accounts, seems to have single-handedly done for the National Front, forerunner to the today's BNP. ${ }^{2}$ In fact, closing down the space in 
this way rarely has the desired effect: once the toothpaste is out of the tube, the can of worms opened, the issues rarely go away - for at least four reasons.

Firstly, such issues are very real, or at least very threatening, for many millions of people (see Sides and Citrin, 2007). Secondly, they are (to coin a phrase) media-sexy, consonant with classic and contemporary 'news values' (see Brighton and Foy, 2007) as well as dovetailing nicely with the political agenda of some media owners. Thirdly, there are enough mainstream politicians prepared to help keep the issues on the boil - even, as Hansen and Koehler (2005: 635-641) show, in Germany, where they are supposedly so determined to head off extremists by offering an apparently more responsible rhetoric on immigration and integration. And, fourthly, those politicians do so - at least in part - because they think the problems warrant talking about and see it as their democratic duty to do so. As Thatcher said, in the same television interview in 1978 , 'We are not in politics to ignore peoples' worries: we are in politics to deal with them.'

There is, in fact, a fundamental question of representation here. Matthew Gibney's highly stimulating attempt to bring together the ethics and politics of asylum gives only the briefest of nods to the party politics surrounding (and possibly also driving) policy and public debate on the topic. But when it does so it leads him to assert the increasing climate of restriction exists 'in part because of the behaviour of irresponsible political elites prepared to use every card in the deck to stay in or to come to power'; instead, he suggests, political leaders should reduce their 'electoral vulnerability' to intolerant and arguably anti-humanitarian public opinion by, among 
other things, a concerted 'attempt to establish greater political bipartisanship on asylum issues' (Gibney, 2004: 245). Only a fully paid up populist, of course, would interpret this as a call for a cosy elite conspiracy designed to deny the people's will, albeit apparently in their own best interests. But it does run the risk of sounding a little like a plea for a kind of 'permissive consensus' that denies the right - and some would say the responsibility - of politicians and their parties to articulate and perhaps even help call forth) widespread public anxiety. This is risky: after all, the clash of socially-embedded (and, yes, socially-constructed and often ill-informed and illiberal) opinion lies at the heart of even the thinnest conception of representative democracy and the good (or at least best-available) governance that is supposed to arise from it. Mainstream parties should not - and, despite the putative 'end of class voting' and 'partisan dealignment' do not (see Thomassen, 2005) - float entirely free of supporters who expect those parties to reflect their sometimes suspicious and even hostile attitude to immigration and the cultural heterogeneity that comes with it.

This genuine (and yet at the same time generated) suspicion and hostility explain why it is not just the issues that hang around. So, too, in many cases do the parties that the centre-right's hard line is supposedly so cleverly designed to defeat. This is partly because by talking about and acting on issues of immigration and integration, the mainstream parties help maintain their salience and therefore the traction of their more extreme counterparts. Whether this is by accident or by design - especially in the case of centre-right parties who stand to gain in terms of their opportunities to form governments - is a moot point (see Bale, 2003). Certainly, there are few centreright parties that have showed much reluctance when it comes to talking up the issues 
concerned - the Swedes (notwithstanding the country's retreat from multiculturalism as detailed by Soininen, 1999) and, until the mid 1990s perhaps, the Italians (Calavita, 1994 and 2004, though see Perlmutter, 1996: 380-1) being the exceptions that seem to prove the rule. Whether acknowledging this fact, and offering up as further evidence the more detailed contributions to the rest of this special issue, will ever make an impact on the gnomic pronouncements of the galacticos of the global intellectual circuit is another matter. Francis Fukuyama, for example, will no doubt continue to insist that Europe, mired in political correctness, has failed to rise to the challenge of an honest and robust debate on integration - particularly of Muslims - because 'political parties on the center-right that should drive such a discussion have been intimidated by the left through accusations of racism and old-style nationalism; they fear above all being tarred by the far right. This is a huge mistake. The far right will make a big comeback if mainstream parties fail to take up this issue in a serious way' (Fukuyama, 2006: 18).

But back to reality, to the continent where the debate conducted by mainstream parties over immigrants and immigration was in the mid 1990s already being called 'chronically populist' (Brubaker, 1995: 908) by one of the many American scholars who really do know what they are talking about. The main point, then, is that to privilege 'reacting to the far right' as the explanatory variable for policy change on migration and multiculturalism effected (or urged on other parties) by the centre right is a mistake. It is no more sensible than, for example, suggesting that migration flows themselves or public anxiety about them - both factors which have impact on parties' policy positions - are determined by the economic logic of late modern liberal 
capitalism or globalization à la, for instance, Saskia Sassen or Alejandro Portes (see Hollifield, 2000: 155-7; though see also Sassen, 2006). Most migration scholars reject such a simplistic analysis when it comes to political economy, so why settle for less when it comes to political competition?

\section{Internal dilemmas and other influences}

Talk of economics and liberalism, however, does serve as a useful warning. We should not allow our desire to question the common wisdom that the mainstream right finds it difficult to talk and act on immigration and integration because they are cross cutting issues (Sciortino, 2000: 224-5; and see Perlmutter, 1996: 377) to go too far. A very clear hard-line stance does indeed jar, potentially at least, with some of the core values of centre right parties. An obvious example would be charity and internationalism for Christian Democrats, who have always been concerned to turn 'strangers into friends' (Hanley, 1994). Another is (economic) freedom from interference by big government for Conservatives and Liberals. Some tensions exist more in some parties, and in some countries, than in others. They are also played out against a context in which both personal and factional ambition loom large, and in which links with traditionally friendly interest groups also matter. Italy, which is a particularly interesting case because the 'mainstream' centre-right (in the guise of Forza Italia plus sundry smaller centrist and Christian Democratic parties) has actually governed alongside the more 'extreme' right, the Lega Nord and the (increasingly 'respectable') Alleanza Nationale (see Ignazi, 2005). Prior to the election of 2001, Berlusconi was counselled by his advisers to 'ride the tiger' of 
immigration (Calavita, 2004: 362); after it, he sometimes appeared to be 'contracting out' policy to Bossi and Fini. Yet the resulting, and apparently harsh, immigration law that bore their names was almost certainly diluted according to a tradition whereby the needs of employers and the pleas of charities, both echoed by other parties in the right-wing coalition, lead to multiple amendments (see Zaslove, 2006) and unreliable implementation - a tradition which Berlusconi did little or nothing to change in this (or in many other) cases.

Whether the centre-right's traditional 'will to power' (which might suggest a hard line to match public opinion) will automatically trump its 'conscience' or at least its ambivalence on immigration and integration (which might lead to something a little softer) is a moot point - especially since everything we know about parties tells us that they are not wholly (or at least not wholly office-seeking) rational actors. We also know that, however much we are convinced we can sort individual organisations in each country into cross-national 'party families', the differences between them often occur, and are due in no small part to their being the products of places as much as ideas. While neither geography nor history is destiny, any trade-off made by centre-right parties between restriction and permissiveness, and between votes and values, is path-dependent and therefore in part contingent on the following: on whether the centre-right parties in question operate in sender or receiver countries; on their welfare state regimes; on the vulnerability of their physical borders; on their traditions of assimilation or multiculturalism; on other national traditions like Commonwealth or republican solidarity, or self-definition as an asylum country; on 
the extent to which security from, for example, terrorist attack is an issue; and, of course, on their attitude to EU enlargement, actual and potential.

\section{Cases and questions}

Hence we have tried in this special issue to select cases from countries that vary as much as possible on these variables, although research on migration policy and politics in Central and Eastern Europe, we reluctantly concluded, was not yet sufficient for us expand our exploration between the 'old' member states. Two examples of the latter hopefully provide an illustration of the range our selection provides: Germany has a 'continental' insurance-based welfare system, is extremely vulnerable to land-based incursion, received immigrants as guest-workers rather than former colonials, previously had one of the world's most generous asylum regimes, has so far avoided an attack by Islamist terrorists, and worked hard for the 2004 enlargement but is distinctly cagey about Turkish entry; Great Britain, on the other hand, has an Anglo-Saxon welfare regime, is an island, became multicultural as a result of its imperial past, saw 'her majesty's opposition' propose withdrawal from the 1951 UN Convention on Refugees at the 2005 general election, has suffered multiple terrorist attacks in recent years, suffered a public backlash against a supposed 'flood' of Eastern European workers following enlargement, but continues as a strong supporter of Turkish entry.

The immediate aim of this special issue is to map and explain the conduct and stance of the centre-right parties in a number of European countries (and in Europe's unique 
trans- or supra-national setting) on the issues of immigration and immigrant integration. In so doing it acknowledges, indeed it stresses, variation - not just according to geography and history, but also according to changing flows and, indeed, foes. Positions or actions taken by parties will, then, fluctuate over time even if we can claim to detect some underlying ideological consistency. Shifting perceptions of what works, both electorally and in terms of interparty alliances also make a difference: the Swedish Liberals, for instance, did well out of campaigning for language tests in 2002 and then said virtually nothing about them in 2006, partly in order to ensure their membership (and the stability) of the centre-right's pre-electoral (and, as it turned out, post-electoral) pact. Meanwhile the British Conservatives (who are apparently anxious to learn as much as they can from the Swedish example) seem unlikely to 'bang on about' immigration next time as they did in 2005: whatever else their then leader, Michael Howard, did for the party, he surely tested to destruction that particular route back to power, although his successor, David Cameron, will almost certainly hear calls for a return to populism if his Swedish-style modernisation doesn't appear to be delivering the electoral goods.

But that, of course, is a very particular matter. We are more interested in more general questions - ones we try to answer in the conclusion. Firstly, while we, no more than others, 'believe that parties are the sole determinants of migration forces' (Triadafilopoulos and Zaslove, 2006: 189), have we established that they are indeed more important than some give them credit for? Secondly, how much is the role and behaviour of centre-right parties in particular more than a function of the 
threat posed by parties on their far-right flank? Thirdly, what are the internal tensions and dilemmas they face?

Last but not least, we need to assess whether the attempt to bring together our 'separate tables' - or at least some of the diners around them - is a useful one. Does it make sense for those interested in political parties to get their head around public policy? Likewise, those interested in migration have won their battle to 'bring the state back in' when it looked at one stage as if it might disappear under the fashionable weight (and essentially 'apolitical logic') of globalization theory (see Hollifield, 2000). Having done so, is it worth their taking more seriously an institution that in liberal democracies is charged with steering that state and providing (however inadequately sometimes) linkage with the citizens from which it supposedly derives its legitimacy and authority? In short, is it time for those who do policy to think, as a stimulating but all too brief contribution written over a decade ago (Perlmutter, 1996) put it, about 'bringing parties back in'?

\section{References}

Bale, T. (2003) 'Cinderella and her ugly sisters: the mainstream and extreme right in Europe's bipolarising party systems', West European Politics, 26 (3): 67-90.

Bale, T., Green Pedersen, C., Krouwel, A., Luther, K.R., and Sitter, N. (2007) 'If you can't beat them, join them? Exploring the European centre-left's turn against migration and multiculturalism: a four-country case study'. Unpublished MS. 
Börzel, T.A. (2002) 'Member State Responses to Europeanization' Journal of Common Market Studies 40 (2): 193-214.

Brighton, P. and Foy, D. (2007) News Values (London: Sage).

Brubaker, R. (1995) 'Comments on "Modes of Immigration Politics in Liberal Democratic States"”, International Migration Review, 23 (4): 903-908.

Budge, I. and Farlie. D (1983) Explaining and Predicting Elections: Issue Effects and Party Strategies in Twenty-Three Democracies, London: Allen \& Unwin.

Calavita, Kitty (1994) 'Italy and the new immigration', in W.A. Cornelius, P.L. Martin and J.F. Hollifield (eds.), Controlling Immigration: a Global Perspective, Stanford: Stanford University Press.

Calavita, Kitty (2004) 'Italy: economic realities, political fictions, and policy failures', in W.A. Cornelius, T. Tsuda, P.L. Martin and J.F. Hollifield (eds.), Controlling Immigration: a Global Perspective. Second Edition, Stanford: Stanford University Press.

Carter, E. (2005) The Extreme Right in Western Europe: Success or Failure? Manchester: Manchester University Press. 
Collyer, M. (2006) Migrants, migration and the security paradigm: constraints and opportunities', Mediterranean Politics, 11 (2): 255-270.

Entzinger, Han (2003) 'The rise and fall of multiculturalism: the case of the Netherlands' in Christian Joppke and Ewa Morawska (eds,) Toward Assimilation and Citizenship: Immigrants in Liberal Nation States (Basingstoke: Palgrave).

Freeman, G.P. (1995) 'Modes of Immigration Politics in Liberal Democratic States', International Migration Review, 29 (4): 881-902.

Fukuyama , Francis (2006) 'Identity, Immigration and Liberal Democracy', Journal of Democracy, 17 (2), pp. 5-20.

Gabel, M.J. and Anderson, C.J. (2002) 'The structure of citizen attitudes and the European political space.' Comparative Political Studies, 35(8): 893-913.

Geddes (2003) The Politics of Migration and Immigration in Europe (London: Sage).

Gibney, M.J. (2004) The Ethics and Politics of Asylum: Liberal Democracies and the Response to Refugees, Cambridge, Cambridge University Press.

Givens, T. and Luedtke, A. (2005) 'European Immigration Policies in Comparative Perspective: Issue Salience, Partisanship and Immigrant Rights', Comparative European Politics, 3 (1): 1-22. 
Hammar T. (1985) (ed.), European Immigration Policy, Cambridge University Press:

Cambridge.

Hampshire, J. (forthcoming) 'Disembedding Liberalism? Immigration Politics and Security in Britain since $9 / 11^{\prime}$ in G. Freeman, T. Givens, and D. Leal (eds), Immigration and Refugee Policy in a Post-9/11 World. Basingstoke: Palgrave.

Hanley, D. (1994) 'Christian Democracy as a political phenomenon,' in Hanley (ed.), Christian Democracy in Europe: A Comparative Perspective, London: Pinter.

Hansen, R. (2002) 'Globalization, Embedded Realism and Path Dependence', Comparative Political Studies, 35: 259-283.

Hansen, R. (2003) 'Migration to Europe since 1945: Its history and its lessons', Political Quarterly, 74 (1): 25-38.

Hansen, R. and Koehler, J. (2005) 'Issue definition, political discourse and the politics of nationality reform in France and Germany', European Journal of Political Research, 44: 623-644.

Hix, S. and Noury, A. (2007) 'Politics, not economic interests: determinants of migration policies in the European Union', International Migration Review, 41 (1): 182-205. 
Hollifield, James F. (1994) 'Immigration and republicanism in France: the hidden consensus', in W.A. Cornelius, P.L. Martin and J.F. Hollifield (eds.), Controlling Immigration: a Global Perspective, Stanford: Stanford University Press.

Hollifield, J.F. (2000) 'The politics of international migration': how can we "bring the state back in"?', in C. B. Brettel and J.F. Hollifield (eds.) Migration Theory: Talking Across Disciplines (London: Routledge).

Ignazi, P. (2005) 'The extreme right', South European Society and Politics, 10 (2): 333-349.

Imbeau, L.M., Pétry, F. and Lamari, M. (2001) 'Left-right party ideology and government policies: a meta analysis', European Journal of Political Research, 40 (1): $1-29$.

Joppke, C. Joppke, Christian (2007) 'Beyond national models: Civic integration policies for immigrants in Western Europe', West European Politics, 30 (1): $1-22$

Karyotis, G. (2007) European migration policy in the aftermath of September 11: the security migration nexus', Innovation, 20 (1): 1-17. 
Lahav, G. (1997) 'Ideological and party constraints on immigration attitudes on Europe', Journal of Common Market Studies, 35 (3): 377-406.

Lahav, G. and Guiraudon, V. (2006) 'Actors and venues in immigration control: closing the gap between political demands and policy outcomes', West European Politics, 29 (2): 201-223.

Lavenex, S. (2006) 'Asylum Policy' in Paolo Graziano and Maarten P. Vink (eds.) Europeanization: New Research Agendas (Basingstoke: Palgrave Macmillan).

Mair, Peter (2006) 'Political Parties and Party Systems' in Paolo Graziano and Maarten P. Vink (eds.) Europeanization: New Research Agendas (Basingstoke: Palgrave Macmillan).

Martin, P.L. (1994) ‘Germany: reluctant land of immigration', in W.A. Cornelius, P.L. Martin and J.F. Hollifield (eds.), Controlling Immigration: a Global Perspective, Stanford: Stanford University Press.

McElroy, G. and Benoit, K. (2007) 'Party Groups and Policy Positions in the European Parliament', Party Politics 13 (1): 5-28.

Meguid, B. (2005) 'Competition between Unequals: The Role of Mainstream Party Strategy in Niche Party Success.' American Political Science Review, 99 (3): 347-59. 
Messina, A.M. (2007) The Logics and Politics of Post-WWII Migration to Western Europe (Cambridge: Cambridge University Press).

Minkinberg, M. (2002) 'The new radical right in the political process: interaction effects in France and Germany', in M. Schain, A. Zolberg, and P. Hossay (eds.) Shadows Over Europe: the Development and Impact of the Extreme Right Wing in Western Europe. Basingstoke: Palgrave Macmillan.

Money, J. (1997) 'No Vacancy. The Political Geography of Immigration Control in Advanced, Market Economy Countries', International Organization 51 (4): 685-720.

Mudde, C. (2007) Populist Radical Right Parties in Europe. Cambridge: Cambridge University Press.

Müller, W.C. and Strøm, K (eds.) (1999) Policy, Office, or Votes? How Political Parties in Western Europe Make Hard Choices, Cambridge: Cambridge University Press.

Panebianco, A. (1988) Political Parties: Organization and Power, Cambridge: Cambridge University Press.

Perlmutter, T. (1996) 'Bringing parties back in: comments on "Modes of immigration politics in Liberal Democratic Societies", International Migration Review, 30: 375-388. 
Rydgren, J. (2005) Movements of Exclusion: Radical Right-Wing Populism in the Western World. New York: Nova.

Sassen, S. (2006) 'The de-nationalization of the state and the re-nationalization of political discourse over immigration', in M. Giugni and F. Passy (eds.) Dialogues on Migration Policy. Lanham: Lexington Books.

Schain, Martin (1999) 'Minorities and Immigrant Incorporation in France in Christian Joppke and Steven Lukes (eds.) Multicultural Questions, Oxford: Oxford University Press.

Schain, Martin (2006) 'The extreme-right and immigration policy-making: measuring direct and indirect effects', West European Politics, 29 (2): 270-289.

Schmidt, M.G. (1996) 'When parties matter: a review of the possibilities and limits of partisan influence on public policy', European Journal of Political Research, 30 (2): $155-183$.

Sciortino, G. (2000) 'Toward a political sociology of entry policies: conceptual problems and theoretical proposals', Journal of Ethnic and Migration Studies, 26 (2): 213-228. 
Sides, J. and Citrin J. (2007) 'European opinion about immigration: the role of identities, interests and information', British Journal of Political Science, 37: 477-504.

Soininen, Maritta (1999) “"The Swedish model” as an institutional framework for immigrant membership rights', Journal of Ethnic and Migration Studies, 25 (4): $685-702$.

Spencer, Ian (1997) British Immigration Policy since 1939: the Making of Multicultural Britain. London: Routledge.

Statham, P. 'Understanding anti-asylum rhetoric: restrictive politics or racist publics? 'Political Quarterly. 74(1):163-177.

Thomassen, J. (ed) (2005) The European Voter: A Comparative Study of Modern Democracies, Oxford: Oxford University Press.

Triadafilopoulos, T. and Zaslove, A. (2006) 'Influencing migration policy from inside: political parties', in M. Giugni and F. Passy (eds.) Dialogues on Migration Policy. Lanham: Lexington Books.

Williams, M.H. (2006) The Impact of Radical Right-Wing Parties in Western Democracies. New York: Palgrave. 
Zaslove, A. (2006) 'The politics of immigration: a new electoral dilemma for the right and the left', Review of European and Russian Affairs, 2 (3): 10-36. 
${ }^{1}$ This special issue began as a workshop in an ESRC-funded seminar series on the Contemporary Right in Europe which was organised out of the University of Sussex but which also met at University College London, and the Universities of Antwerp, Cambridge and Leiden, thanks to (among others) Sean Hanley, Steven van Hecke and Sarah de Lange, Julie Smith and Petr Kopecky. Details can be found at http://www.sussex.ac.uk/sei/1-4-9.html. Whether the relative neglect of the centre-right is due to what are widely assumed to be the more left-wing preferences of political scientists, or to the definitional problems surrounding a space in the political spectrum that is shared by a number of party families (the subject of another workshop in the series), is a moot point. Here we take a 'big-tent' approach: by centre or mainstream right we include market (but not social) liberal parties, Christian Democrats and conservative parties - in short those party families (excluding Agrarian/Centre and Regionalist parties) which tend to score five or above on most expert surveys but which are not part of the populist radical right (or simply far-right) party family.

${ }^{2}$ Anyone interested in reading the full text of the interview in January 1978 can find it at http:// www.margaretthatcher.org/speeches/displaydocument.asp?docid=103485. At the time, it seemed clear to most observers that the remarks, inasmuch as they had a strategic purpose, as well as presaging what within a year or two became a government policy, were intended to target working-class Labour voters in general rather than those were flirting with the NF in particular (see http://www.time.com/time/ magazine/article/0,9171,948011,00.html). 